\title{
The Effort to Foster Civic Virtue in Elementary Schools
}

\section{May Nisa Istiqomah"), Mirza Hardian'), Yayuk Hidayah ${ }^{3)}$, Nufikha Ulfah ${ }^{4)}$}

Elementary School 4 Darmakradenan, Ajibarang, Banyumas, Indonesia ${ }^{1)}$

Primary teacher Education, Universitas Ahmad Dahlan, Yogyakarta, Indonesia ${ }^{2)}$

Extraordinary Lecturer MKI, Universitas Ahmad Dahlan, Yogyakarta, Indonesia ${ }^{3)}$

Pancasila and civic education, Universitas Riau, Indonesia ${ }^{4)}$

yayuk.hidayah@pgsd.uad.ac.id

\begin{abstract}
This study aims to explore the efforts of civic virtue coaching in elementary schools. The research method used is descriptive qualitative - retrieval of data through observation, interviews, and documentation. Data analysis uses the Miles and Huberman model. The subjects of the study were the first-grade students of SD N 4 Darmakradenan, Ajibarang, Banyumas, Indonesia, 2019/2020 academic year. The results showed that the development of Civic Virtue in Elementary Schools at SD N 4 Darmakradenan Ajibrarabang Banyumas was formulated by instilling Civic Virtue concepts on a scale of concept recognition about nationality to foster a sense of love for the motherland. Besides, the findings also confirm that Pancasila Education and Citizenship (PPKn) in Elementary Schools serve as a bridge in the efforts to foster Civic Virtue in Primary Schools 4 N Darmakradenan, Ajibarang, Banyumas. Further research on the opportunity to encourage Civic Virtue in Primary Schools is recommended in a new study in this article

Keywords: Civic Virtue, Elementary School, Coaching.
\end{abstract}

\begin{abstract}
Abstrak. Penelitian ini bertujuan untuk mengeksplorasi usaha pembinaan civic virtue di Sekolah Dasar. Metode penleitian yang digunakan adalah kualitatif deskriptif. Pengambilan data melalui observasi, wawancara, dan dokumentasi. Analisi data menggunakan model Miles dan Huberman. Subjek penelitian adalah siswa siswi kelas 1 SD N 4 Darmakradenan, Ajibarang, Banyumas, Indonesia,Tahun ajaran 2019/2020. Hasil penelitian menunjukkan bahwa pembinaan Civic Virtue di Sekolah Dasar di SD N 4 Darmakradenan Ajibrarabang Banyumas di formulasikan dengan menanamkan konsep-konsep Civic Virtue dalam skala pengenalan konsep tentang kebangsaan sehingga dapat menumbuhkan rasa cinta tanah air. Selain itu, hasil temuan juga menegaskan bahwa Pendidikan Pancasila dan Kewarganegaan (PPKn) di Sekolah Dasar menjadi jembatan dalam upaya pembinaan Civic Virtue di Sekolah Dasar SD N 4 Darmakradenan, Ajibarang, Banyumas. Penelitian lebih lanjut tentang peluang pembinaan Civic Virtue di Sekolah Dasar di anjurkan dalam penelitian selanjutnya dalam artikel ini.
\end{abstract}

Kata Kunci: civic virtue, sekolah dasar, pembinaan. 


\section{INTRODUCTION}

Education is an important part of human life, in KBBIEducation comes from the words' educate 'and get the affirmation of' pe 'and suffix', which is interpreted as a process or way of educating (Depdikbud, 1991).Education leads people to become human beings with the values of the prevailing norms. Education is the deliberate effort of parents in giving rise to moral responsibility (Muhibbin, 2007). As an important aspect, education certainly has various scopes in its studies. Furthermore, when faced with globalization, education in the era of globalization makes local wisdom important (Hidayah, Feriandi, \& Saputro, 2019).

Civic virtue coaching in elementary schools is an attempt to respond to the fact that differences are present in each student in school. The initial concept of developing civic virtue in Elementary Schools was based on the postulate that every student in Elementary School was part of Indonesian citizens who would carry out their lives as Indonesian citizens. Students have different characteristics from their background, race, culture, religion and gender (Baehaqi, 2014). Blanken (2012) in Syarifa (2019) explains that civic virtue is part of the policy between citizens and the state or with the community. While Quigley in Winataputra \& Budimansyah (2007) argues that civic virtue is the willingness of citizens to be able to put public interests beyond personal interests.
SD N 4 Darmakradenan Ajibrarabang is one of the elementary schools in Banyumas. As a formal educational institution, SD N 4 Darmakradenan Ajibrarabang also has an educational function as stipulated in Law No. 20 of 2003 concerning the National Education System. The school is hope in instilling character values (Retnasari \& Suharno, 2018). Characteristics of elementary school students in the form of a desire for concrete interests, have high curiosity, love to form peer groups that make learning in elementary schools a good time to provide an understanding of moral values that prevail in society. Studies that discuss domain-specific concepts regarding politics that are understood by children show that even children in first grade have political knowledge that becomes increasingly different over time in elementary school. Fourth graders' knowledge is more complicated than first graders. Children's migrant backgrounds have a negative influence on political knowledge. However, no gender-specific differences in knowledge are found (Goetzmann, 2017) meanwhile, specific criticisms of elementary school philosophy courses suggest how the experience of teaching philosophy to children using picture books can enrich learning in higher education (Wartenberg, 2012) furthermore, studies that exploit two primary school interventions to estimate the long-term impact of postsecondary achievement find suggestive evidence that behavioural interventions for 
high-achieving students in high-performing students, while curricular interventions more influence the results of lectures for students who have medium to medium performance height (Hemelt, Roth, \& Eaton, 2013)

Previous research on civic virtue coaching was civic virtue coaching through character education in SMP 25 Bandung, one of which resulted in the character education program at SMP Negeri 25 Bandung supporting efforts to develop civic virtue (Lutfiani, 2018). Civic virtue coaching research through urban agriculture programs in Bandung resulted, the first urban agriculture program is an education for the public towards greening awareness. Second, the provision of green space is beneficial to public health. Third, urban agriculture programs can increase food security businesses (Prasetiyo, 2016). Civic virtue fostering research with an emphasis on the social field resulted in ACT infrastructure in the form of digital philanthropy and voluntarism being able to foster civic civilization, this was marked by increased public participation in the sociocultural field (Nurdiyanti, 2019). Research on the development of citizenship civilization in the social field results in that a peaceful education program within the Peace Generationter community can improve citizenship civilization with the result that it can have social responsibility (Zurgobban \& Budimansyah, 2016).
Based on the results of these studies have illustrated that civic virtue coaching efforts have land and opportunities in the field and can be in school or the community. Through the results of previous studies, there is also no research that examines the development of civic virtue at SD $\mathrm{N} 4$ Darmakradenan, Ajibarang, Banyumas, Indonesia. Thus through this research, the research team tried to provide content on the emptiness of civic virtue coaching research in Elementary Schools, specifically SD N 4 Darmakradenan, Ajibarang, Banyumas, 2019/2020 academic year.

These various descriptions bring researchers to research the development of civic virtue at SD $\mathrm{N} 4$ Darmakradenan, Ajibarang, Banyumas, 2019/2020 academic year. The selection of SD N 4 Darmakradenan, Ajibrarabang, Banyumas as research locations for several reasons. First, SD $\mathrm{N} \quad 4$ Darmakradenan, Ajibarang, Banyumas has a strategic location as a research location with the theme of developing civic virtue in elementary schools. Second, consideration of the cost, time and energy possessed by the research team. This research formula is 1) What is the process of civic virtue coaching in SD N 4 Darmakradenan, Ajibarang, Banyumas, 2019/2020 school year?

2) What obstacles and efforts arise in the formation of civic virtue in SD $\mathrm{N} 4$ Darmakradenan, Ajibarang, Banyumas, Know the teachings of 2019/2020? The benefits of 
civic virtue coaching research at SD N 4 Darmakradenan, Ajibarang, Banyumas are theoretically reinforced in the PPKn SD study while producing students who have civic virtue which is an important part of the culture of citizenship in a pluralist society in Indonesia. Practical benefits for elementary school teachers can empirically provide information about efforts to embody civic virtue in SD N 4 Darmakradenan, Ajibarang, Banyumas. Schools can be taken into consideration in the formulation of policies in learning so that civic virtue coaching can be one of the programs for schools. For Pancasila and Citizenship Education academics, the results of this study can enrich the PPKn's lack of knowledge, especially in elementary schools.

\section{RESEARCH METHODS}

This qualitative research was conducted in July-September 2019. Qualitative research was used to answer the problem statement 1) What is the process of fostering the benevolence of citizens in $\mathrm{SD} \quad \mathrm{N} \quad 4$ Darmakradenan, Ajibarang, Banyumas, 2019/2020 school year? 2) What obstacles and struggles have arisen in fostering the virtues of citizens in SD N 4 Darmakradenan, Ajibarang, Banyumas, Know the teachings of 2019/2020? Retrieval of data through observation, interviews, and documentation. 10 students of grade 1 SD N 4 Darmakradenan, Ajibarang, Banyumas and a grade 1 teacher at SD N 4
Darmakradenan, Ajibarang, Banyumas were interviewed to get information about citizenship development at $\mathrm{SD} \quad \mathrm{N} \quad 4$ Darmakradenan, Ajibarang, Banyumas. Data analysis techniques used by researchers by using the model of Miles and Huberman in the form of data reduction, data presentation and drawing conclusions (Miles \& Huberman, 1992)

\section{DISCUSSION}

Based on the The problem statement which have been outlined in this study, the results and discussion are divided into two parts of the discussion which are divided into each sub-chapter, namely, the process of civic virtue formation at SD N 4 Darmakradenan, Ajibarang, Banyumas, and Kenadala and what efforts are made appeared in the guidance of civic virtue at SD $\mathrm{N} 4$ Darmakradenan, Ajibarang, Banyumas.

Problem formulation 1, What is the process of developing civic virtue at SD N 4 Darmakradenan, Ajibarang, Banyumas, Banyumas, 2019/2020 school year ?. Discussion on the formulation of the first problem researchers get from the data researchers get through observation and interviews. In addition, the results of the documentation that researchers do also turn and provide reinforcement to the discussion of the first problem formulation. Civic virtue guidance in grade 1 SD N 4 Darmakradenan, Ajibarang, Banyumas is carried out 
systematically and planned by the teacher. The curriculum used by SD N 4 Darmakradenan, Ajibarang, Banyumas is the 2013 curriculum. Mauritz Johnson in Sukmadinata (2001) describes the curriculum as an educational plan, guidelines and process. Based on the condition of the class which is a grade 1 elementary school. The teacher applies the guidance of civil virtue while remaining oriented to the theory of teaching at an early age. Referring to Law No. 20 of 2003 early childhood education is "a coaching effort that encourages children from birth to the age of six years carried out through the assistance of stimuli to foster growth and physical development and well-being to support the preparation of further education" then at the elementary school stage 1 elementary school $\mathrm{N}$ 4 Darmakradenan, Ajibarang, Banyumas prepares learning for students to be able to do or feel. The following stages of fostering citizens in grade 1 SD N 4 Darmakradenan, Ajibarang, Banyumas are as follows:

\section{Planning Steps}

In the thematic learning planning stage,

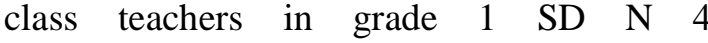
Darmakradenan, Ajibarang, Banyumas carry out several activities, namely mapping basic competencies, setting themes, and developing thematic lesson plans. In the Coaching of civic virtue in grade 1 SD N 4 Darmakradenan, Ajibarang, Banyumas, the class teacher slipped the virtues of the citizens in the learning plan. The values of civil virtue contained in the RPP for grade 1 teachers at SD N 4 Darmakradenan, Ajibarang, Banyumas are as follows:

Table 1: values of civic virtue in elementary $\begin{array}{llllll}\text { school teachers grade } & 1 & \text { RPP } & \mathrm{N} & 4\end{array}$ Darmakradenan, Ajibarang, Banyumas

\begin{tabular}{|l|l|l|}
\hline No & Nilai-Nilai Civic Virtue Yang Ada Dalam RPP & \multicolumn{1}{|c|}{ Keterangan } \\
\hline 1 & $\begin{array}{l}\text { Patuh terhadap peraturan } \\
\text { Di padukan dengan model } \\
\text { pembelajaran }\end{array}$ \\
\hline 2 & Menghargai perbedaan & $\begin{array}{l}\text { Di padukan dengan model } \\
\text { pembelajaran }\end{array}$ \\
\hline 3 & Kerukunan & $\begin{array}{l}\text { Di padukan dengan model } \\
\text { pembelajaran }\end{array}$ \\
\hline 4 & Bekerjasama & $\begin{array}{l}\text { Di padukan dengan model } \\
\text { pembelajaran }\end{array}$ \\
\hline 5 & $\begin{array}{l}\text { Saling menghormati } \\
\text { Di padukan dengan model } \\
\text { pembelajaran }\end{array}$ \\
\hline
\end{tabular}

Source: Research Data, 2019

In the planning stage, the teacher at SD N 4 Darmakradenan, Ajibarang, Banyumas has compiled a level of learning by integrating the development of civic virtue values. In the success of the 2025 gold Indonesia, character building is an important part in overcoming character crisis (Zuriah, Widodo, \& Sunaryo, 2016) thus by carrying out missions in accordance with the learning outcomes of grade 1 teachers at SD N 4 Darmakradenan, Ajibarang, Banyumas prepare learning based on civic virtue values.

In the effort to develop civic virtue in grade 1 SD N 4 Darmakradenan, Ajibarang, Banyumas, the planning stage is the first step in realizing learning objectives, especially the emphasis on fostering civic virtue. In the planning stage, the teacher strives for learning material by including citizenship values. In addition, the teacher also emphasizes the basic 
introduction of the state, Pancasila, to the students. Making Pancasila moral literacy (Dianasari \& Hidayah, 2019).

The coaching of Civic virtue at the elementary school level can follow the class composition so that the teacher can adjust the learning patterns. Research examining the relationship between the quality of teacherchild relationships and behaviour problems among School students on 1,364 children from birth to adolescents found two things: highquality teacher-child relationships predict lowlevel externalizing behaviour. Second, highquality relationships act as protective factors, helping to prevent children with high-level internalizing behaviour in early childhood from developing trajectories of long-term internalizing behaviour problems (O'Connor, Dearing, \& Collins, 2011).

\section{Planning Stage}

Stages of the implementation of learning based on the values of civic virtue teacher divide into three (3) parts in the form of the first part are the opening in the form of classroom conditioning, conveying the competencies to be learned. Second is the core part, at the core of the class 1 teacher at SD N 4 Darmakradenan, Ajibarang, Banyumas, the teacher conducts learning with a scientific approach. The success of learning can be influenced by the strategies that teachers use (Hidayah, Yayuk, Ulfah Nufikha, Suyitno, 2019). The teacher carries out the process of observing and gathering information on students' development related to civic virtue, including tolerance, respect, and cooperation under the lesson plan.

The implementation of learning to develop civic virtue is in line with the opinion of Sudjana (2010) which states that learning is steps arranged in such a way as to achieve the expected results. The development of civic virtue class 1 SD $\mathrm{N} 4$ Darmakradenan, Ajibarang, Banyumas also pays attention to the relationship between teachers and students. A study analyzing the many reforms of education since the No Child Left behind Act (US Department of Education, 2001) found that teachers reported causes of personal and contextual stress. Concrete examples of five categories of contextual stressors that teachers identify: political and educational structures, teaching factors, student factors, parent and family factors, and school climate (Stauffer \& Mason, 2013)

The development of civic virtue class 1 at SD N 4 Darmakradenan, Ajibarang, Banyumas also cannot be separated from the theory of early childhood learning. Characteristics of early childhood is to have a great curiosity, unique personality, imagination, showing egocentric, is a potential time for learning, has a short span of concentration span (Aisha, Siti, 2010). In establishing civic virtue in grade 1 SD N 4 Darmakradenan, Ajibarang, Banyumas the teacher often uses the singing method. Based 
on the results of research on educators understanding of children's songs as forming children's characters early on, it is found that repeated habituation is beneficial in shaping children to have positive characters, there are educator messages in song lyrics (Riwanti, Hardika, \& Dayati, 2017).

\section{Closing Stage}

Closing stages in the development of civic virtue class 1 SD N 4 Darmakradenan, Ajibarang, Banyumas is to make a summary of the learning that is just finished, make an assessment, reflect, convey the learning at the next meeting. The development of civic virtue class 1 at SD N 4 Darmakradenan, Ajibarang, Banyumas does not only occur during lessons but also in student activities. The teacher always supervises student activities while at school. In addition, the availability of learning facilities in schools is also used by teachers in supporting the development of civic virtue.

Problem formulation 2, what obstacles and efforts have arisen in developing civic virtue in SD N 4 Darmakradenan, Ajibarang, Banyumas, 2019/2020 school year?

Discussion on the formulation of the problem the two researchers get from the data researchers gets through observation and interviews. In addition, the results of the documentation that researchers do also contribute to strengthening the discussion on the formulation of the second problem.
The obstacle to developing civic virtue in SD N 4 Darmakradenan, Ajibarang, Banyumas, Banyumas is the lack of cooperation between schools and parents. The Role of the Family (Lack of awareness of the responsibility in shaping the morale of children and parents pay less attention to the quality of parenting). This study examines the level and impact of five types of parental involvement on the academic achievement of elementary school children based on race/ethnicity, poverty, and educational attainment of parents. The sample consisted of 415 third- to fifth-grade students who completed the Primary School Success Profile. Consistent with the theory, parents with different demographic characteristics showed different types of involvement, and the type of involvement shown by parents from dominant groups had the strongest relationship with achievement. (J.-S. Lee \& Bowen, 2006).

We often hear that the family is the first educational institution in shaping the character of children. Based on qualitative interviews with divorced mothers, research focused on mothers' attitudes toward father involvement in parenting after divorce. Produces three postdivorce care patterns: (1) cooperative care with non-resident fathers who are involved with their children, (2) distant care characterized by loose contact between children and nonresident fathers, and (3) the care of an only child without a father at all. Financial involvement or support (Hansson, 2010). 
Parents are their first teachers in moral education that has the longest influence on children's moral development, so the good and bad character of a child is largely determined by the quality of parenting. In a study, the expression raised by parents on moral problems affecting their children will be seen as a result of how parents provide moral education to their children. Parents who are aware and caring when their children are caught doing a disappointing action asking their children to regret their actions, find out what the children have done wrong, bring up the attitude of responsibility and ask them to apologize and correct their mistakes, people Unconscious and caring parents will do the opposite. The quality of childcare is the basis for the measurement used by children in various problems. The greater the attitude of love and affection between the child and the two parents, the less likely the child is involved in the problem, and vice versa (Lickona, n.d., pp. 48-50)

Efforts in dealing with the constraints of civic virtue in SD N 4 Darmakradenan, Ajibarang, Banyumas are the main companions between school and parents. The child's primary companion in developing his character should be a partner who can share as a friend. The good attitude a child has, which is formed at school will slowly disappear if the values taught at school do not have the support of parents and family environment (Lickona, n.d.). Parents and teachers should act as good models for students or their children. For example, teachers and parents are able to show examples of good attitudes and behaviours when solving problems experienced by children such as fairness, respect for the child's opinion, politely criticizing people, and so on. However, if teachers and parents behave the opposite way, children will unconsciously imitate it. Therefore, teachers and parents must be careful when speaking and acting, so that negative values are not embedded in the child's heart. Besides that, teachers and parents need to have assertive skills, namely the ability to express opinions openly using a way that does not hurt the feelings of others and listening skills, namely listening skills with full understanding and critical. Both must be developed in a balanced way. Exemplary values such as those described are one element of the way that can be done, in the education of values and spirituality known as a comprehensive method (Zuchdi, 2009, pp. 4748)

\section{CONCLUSION}

Our research is aimed at exploring civic virtue coaching efforts in elementary schools. Based on data analysis and discussion, we state that the answers to the research objectives are firstly the development of Civic Virtue in SD N 4 Darmakradenan, Ajibarang, Banyumas emphasized on Civic Virtue concepts about nationality so that it can foster a sense of patriotism in students. Second, Pancasila and 
Citizenship Education (PPKn) in Elementary Schools is helping in the effort to foster Civic Virtue in Primary Schools at SD N 4 Darmakradenan, Ajibarang, Banyumas. The next idea to be applied in this research is about fostering Civic Virtue in Elementary Schools with broader studies.

Researchers would like to thank SD N 4 Darmakradenan, Ajibarang, Banyumas for allowing researchers to carry out this research. Thank you to grade 1 teachers at SD N 4 Darmakradenan, Ajibarang, Banyumas. Thank you to all parties at SD N 4 Darmakradenan, Ajibarang, Banyumas who have agreed to be interviewed.

\section{REFERENCES}

[1] Aisyah, Siti, D. (2010). Perkembangan dan Konsep Dasar Pengembangan Anak Usia Dini. Jakarta: Universitas Terbuka.

[2] Baehaqi, D. A. (2014). Pengembangan Kebajtkan Kewargaan (Civic Virtue) Dalam Masyarakat Multikultural Indonesia: Peran Pendidikan Kewarganegaraan. In Proceedings seminar nasional Profesionalisme Sebagai Daya Dukung Kualitas Bangsa. Garut: STKIP GARUT PRESS.

[3] Cos, G. C., \& Rossmann, L. C. (1997). Articulating Civic Virtue in the Second 1996 Presidential Debate. American Behavioral Scientist, 40(8), 1123-1132. https://doi.org/10.1177/00027642970400 08011

[4] Depdikbud. (1991). Kamus Besar Bahasa Indonesia. Jakarta: Balai Pustaka.

[5] Dianasari, \& Hidayah, Y. (2019). Pancasila Sebagai Literasi Moral Pada Pendidikan Dasar Di Era Revolusi
Industri 4.0. In Prosiding Seminar Nasional Pendidikan I. Majalengka: Fakultas Keguruan dan Ilmu Pendidikan Universitas Majalengka.

[6] Goetzmann, A. (2017). Elementary School Children's Political Knowledge. American Behavioral Scientist, 61(2), 238-253.

https://doi.org/10.1177/00027642166891 24

[7] Hemelt, S. W., Roth, K. B., \& Eaton, W. W. (2013). Elementary School Interventions: Experimental Evidence on Postsecondary Outcomes. Educational Evaluation and Policy Analysis, 35(4), 413-436.

https://doi.org/10.3102/01623737134931 31

[8] Hidayah, Y., Feriandi, Y. A., \& Saputro, E. A. V. (2019). Transformasi Kearifan Lokal Jawa Dalam Pendidikan Karakter Sekolah Dasar. AULADUNA: Jurnal Pendidikan Dasar Islam, 6(1), 50-61.

[9] Lutfiani, R. S. (2018). Skripsi: Pembinaan Kebajikan Kewarganegaraan (Civic Virtue) Melalui Program Pendidikan Karakter Bandung Masagi (Studi Kasus di SMP Negeri 25 Bandung). Bandung: Universitas Pendidikan Indonesia.

[10] Miles, B. M., \& Huberman, M. (1992). Analisis Data Kualitatif Buku Sumber Tentang Metode-metode Baru. Jakarta: UIP.

[11] Muhibbin, S. (2007). Psikologi pendidikan dengan pendekatan baru. bandung: Pt. remaja rosdakarya.

[12] Nurdiyanti, A. (2019). Thesis: Pembinaan Civic Virtuedi Bidang Sosial Melalui Praktik Filantropi Dan Voluntarisme: Studi Kasus Gerakan Sosial Kemanusiaan Let's ACT Indonesia. Bandung: Universitas Pendidikan Indonesia. 
[13] O’Connor, E. E., Dearing, E., \& Collins, B. A. (2011). Teacher-Child Relationship and Behavior Problem Trajectories in Elementary School. American Educational Research Journal, 48(1), 120-162.

https://doi.org/10.3102/00028312103650 08

[14] Prasetiyo, W. H. (2016). Tesis: Pembinaan Keadaban Kewarganegaraan (Civic Virtue) di Bidang Lingkungan Melalui Program Pertanian Kota (Urban farming) di Kota Bandung. Bandung: Universitas Pendidikan Indonesia.

[15] Retnasari, L., \& Suharno. (2018). Strategi Smp Muhammadiyah Boarding School Yogyakarta Dalam Pembiasaan Karakter Kewarganegaraan Pada Peserta Didik. Citizenship Jurnal Pancasila Dan Kewarganegaraan, 6(1), 52-62. https://doi.org/10.21831/jpk.v7i2.15511

[16] Riwanti, D. W., Hardika, \& Dayati, U. (2017). Pemahaman pendidik tentang makna lagu anak-anak sebagai pembentuk karakter anak usia dini. Ilmu Pendidikan, 2(2), 151-156.

[17] Stauffer, S. D., \& Mason, E. C. M. (2013). Addressing Elementary School Teachers' Professional Stressors: Practical Suggestions for Schools and Administrators. Educational Administration Quarterly, 49(5), 809837.

https://doi.org/10.1177/0013161X13482 578

[18] Sudjana, N. (2010). Dasar-dasar Proses Belajar. Bandung: Sinar Baru.

[19] Sukmadinata, N. S. (2001). Pengembangan Kurikulum (teori dan praktik). Bandung: Remaja Rosdakarya.

[20] Syarifa, S. (2019). Konsep Civic Virtue dan Pendidikan Kewarganegaraan di Indonesia.
[21] Wartenberg, T. E. (2012). Elementary school philosophy: A response. Theory and Research in Education, 10(1), 89-96. https://doi.org/10.1177/14778785124374 74

[22] Winataputra, U. S., \& Budimansyah, D. (2007). Civic Education. Bandung: Prodi Pendidikan Kewarganegaraan UPI.

[23] Zurgobban, Z., \& Budimansyah, D. (2016). Pendidikan damai sebagai pembinaan keadabaan kewarganegaraan di bidang sosial. Modeling: Jurnal Program Studi PGMI, 3(1).

[24] Zuriah, N., Widodo, R., \& Sunaryo, H. (2016). Model pendidikan karakter berbasis nilai kearifan lokal dan civic virtue sebuah rekayasa sosial. In SENASPRO 2016 | Seminar Nasional dan Gelar Produk (pp. 164-177). Malang. 